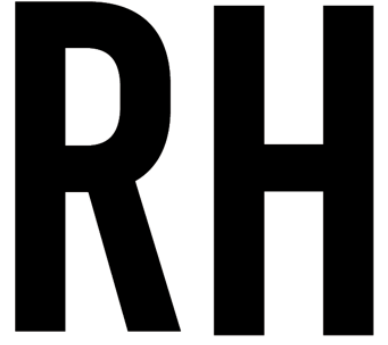

RADICALHOUSINGJOURNAL
Maria Khristine Alvarez is a PhD student at The Bartlett Development Planning Unit, University College London. She is the recipient of the 2018

Gilbert F. White Thesis Award given by the Hazards, Risks, and Disasters Specialty Group of the American Association of Geographers. Her PhD research examines how 'danger zone' evictions as a requirement and consequence of resilience-seeking

in post-Ondoy (2009-present)

Manila transformed coastal and riparian corridors in the urban core and created relocation hubs in the periphery. Contact: alvarez.tin@gmail.com

\section{Benevolent evictions and cooperative housing models in post-Ondoy Manila}

\author{
Maria Khristine Alvarez \\ The Bartlett Development Planning Unit, \\ University College London
}

\begin{abstract}
In this paper, I forward the concept of benevolent evictions to describe a new mode of dispossession, whereby expulsions from the urban core to the periphery are facilitated through the deployment of benevolence as a technology of eviction. Drawing on the experience of a community association in Pasig City, a part of Metro Manila in the Philippines, I examine how benevolent evictions, as materialized in The People's Plan, reconfigured community participation and activist contestations. I distil the politics of participation by troubling practices of inclusion in housing affairs and exclusion in flood control matters; and critically assess the implications of non-transgressive coproduction models on organizing for housing justice. While democratizing housing solutions did not necessarily result in the democratization of participation, I argue that the contradictions that emerge present radical possibilities for rewriting the politics of participation toward the transformation of slum-state and citizen-state relations.
\end{abstract}

\section{Keywords}

flooding, resilience, eviction, participation, Manila

\title{
Introduction
}

Critical scholars have written extensively about the impacts of the 2008 global financial crisis on housing mostly in cities of the global North: from mass foreclosures, a spike in evictions (Byrne, 2018), a crisis of homelessness, an exponential increase in empty homes (Dorling, 2014), to intensified modes of housing financialization (Aalbers, 2017; Fields, 2018), all of which bloomed new housing justice movements. This spring of resistance assembled rent protests (Byrne, 2018) and rent strikes (Cooper \& Paton, 2018), occupations 
and repossession of empty homes (Colau \& Alemany, 2012/2013), and the generation of new housing commons (Joubert \& Hodkinson, 2018). However, as knowledges about the well-represented geographies_or the 'Norths' — of critical academic scholarship proliferate, little remains known about the post-2008 housing scenario in Southern cities that dodged the most injurious impacts of the global financial crisis. The invitation to think through and about the post-crisis appears to carry an assumption that its impacts on housing were somewhat similarly felt across the South; but while there are certainly resonances, there still remains other stories to tell. Thus, this invitation is at the same time a provocation to reflect on the question of 'whose urbanism [we are] interested in' (Maringanti, 2013, p. 2316).

If radical perspectives were to examine the 'global' and the 'post-crisis,' we are compelled to extend our frames beyond both the North and the visible South, to account for the experiences of the souths of the South. Such a reorientation brings into focus the peripheries of critical Southern urban scholarship: places like Metro Manila, the metropolitan center of the Philippines, home to 12,787,669 people (Philippine Statistics Authority, 2015), and 584,425 informal settler families (ICF International, 2014, p. 25), of whom 52,254 were evicted in the name of safe futures and disaster resilience (Alvarez \& Cardenas, 2019). The absence of Manila in conversations and debates on post-2008 housing struggles owes largely to the significantly less adverse impacts of the crisis on the Philippine real estate sector (Ortega, 2016b), vis-à-vis economies and local industries that had greater exposure to the securities and derivatives market. ${ }^{1}$ This important distinction in the experience and aftermath of the 2008 crisis alerts us to difference in the problems that emerge, the questions that are asked, and the processes that are observed.

Understanding the post-2008 housing struggles in Manila therefore requires not merely describing the current juncture, but also interrogating what 'post-crisis' means. This paper takes up this task: it attempts to decenter understandings of the post-2008 housing struggle beyond the financial crisis, by unveiling other processes and phenomena that undergird it, particularly flooding, climate change, and resilience-seeking. The post-2008 housing situation I describe pertains to the eviction crisis produced by responses to escalating concerns over disaster risk reduction management (DRRM) and flood resilience. Specifically, it refers to 'danger zone' evictions following the September 2009 Ondoy (international codename: Ketsana) flood disaster, which introduced a new mode of expulsion I characterize as benevolent eviction. Here, I define benevolent eviction as a mode of dispossession whereby benevolence is deployed as a technology of eviction. Thus, deviating from other contributions in this issue, the 'post-2008' moment I discuss relates not to the global financial crisis but to the Ondoy flood disaster which reconstituted Philippine DRRM policy.

This article is based on research in Manila conducted intermittently in the period September 2015 to August 2018. It employs a critical discourse analysis of two sets of texts: in-depth interviews and conversations with state personnel and consultants, housing advocates, and evicted residents; and secondary sources including policy texts, project information documents, organizational reports, relocation and resettlement action plans

${ }^{1}$ I owe this point to Claudine Alvarez. 
(RRAPs), eviction notices, and correspondence between residents and government authorities. This paper examines Metro Manila evictions as a consequence of resilienceseeking, through the experience of a community organization in Pasig City, ${ }^{2}$ the Alliance of People's Organizations Along Manggahan Floodway (APOAMF), in building an in-city relocation project under a participatory housing program known as The People's Plan. The discussion proceeds in two parts. Part 1 introduces the concept of benevolent evictions: it begins with a description of the climate of evictions prior to and in the immediate aftermath of the disaster, followed by a synthesis of the shift in rhetoric and demeanor of slum evictions. Meanwhile, Part 2 examines how benevolent evictions as a new mode of dispossession reconfigured community housing struggles and activist contestations: it considers the creation of new alliances and strategies, outlines the fragmented and burdensome character of participatory planning, and explains the politics of participation under The People's Plan. It concludes with a critical reflection on the revanchism of benevolence and the radical possibilities presented by contradictions of non-transgressive participation.

\section{Benevolent evictions: a synthesis of origins and shifts}

Manila is in the grip of a systematic eviction crisis facilitated by the state. Between 2012 and 2017, 52,254 informal settler families (ISFs) were evicted under an ambitious plan to remove 104,219 ISFs living in 'danger zones,' as part of flood- and disaster-proofing the city following the September 2009 Ondoy floods that inundated the capital region and surrounding provinces (Alvarez \& Cardenas, 2019). However, 'danger zone' evictions remain unacknowledged as a crisis because it is framed as 'resettlement' and carried out under a 'participatory' in-city housing program. This depoliticization of urban dispossession echoes the neglect of what is in fact a national housing crisis. To put this in perspective, the Housing and Urban Development Coordinating Council estimated a 2.02-million housing need for 2016 (Arcilla, 2018, p. 85). Of 190,413 public housing units completed as of 2016, 114,409 are idle and unoccupied; and of this number, 27,932 are designated for informal settlers (Arcilla, 2018, p. 87). The despondency of these figures vis-à-vis the state's eviction targets looms larger when set against the exponential growth of the real estate sector. But because housing in the Philippines is neither understood as a public good nor as a government obligation, but rather as an individual(ized) responsibility that is privately afforded, concerns over supply, quality, and affordability, as well as of evictions, pose greater problems for the urban poor.

On one hand, housing construction for the middle-class via processes of accumulation squeeze out and dispossess informal settlers residing in spaces earmarked for re/development (Ortega, 2016b). On the other, the design flaws and failures of social housing are socialized onto beneficiaries. The unaffordable amortization rates and impoverished living conditions which drive the rejection of relocation and the renting out and reselling of awarded units, which in turn produce low-occupancy rates, are redistributed

2 Pasig City is located in Metro Manila, whose jurisdiction comprises 16 cities and one municipality. 
onto beneficiaries (Arcilla, 2018). The confluence of these burdens produces social housing as a crucial neoliberal tool for facilitating gentrification and credit-led accumulation (Arcilla, 2018), thereby reproducing rather than solving the problem of homelessness and housing precarity. As designed and implemented across administrations, the Philippine state's response to shelter needs - whether through building more relocation housing for informal settlers or outsourcing housing supply for the middle-class to developers-has left the poor invariably worse-off. This outcome is most salient in urban areas where both interventions have led to evictions, particularly through the justification of slum removals.

The exponential growth of real estate in Metro Manila and its suburbs has been accompanied and aided by the demolition of informal settlements (Ortega, 2016b). Since slum evictions are enacted as demolitions, evictions have been historically violent in both form and conduct. The presence of the local police, required under the Urban Development and Housing Act to facilitate the orderly removal of slum dwellers, has often provoked physical violence. Because evictions are essentially forced even when prior consent is procured, it is not uncommon for residents to resist and fight back during demolitions. Yet time and again, the state has blamed this defense of life and home for clashes, injuries, and deaths (Ortega, 2016b).

Fueled by anti-slum discourses of the September 2009 Ondoy disaster, the rhetoric and demeanor of slum evictions in the immediate aftermath of the floods conformed to this violence (Alvarez \& Cardenas, 2019). Blamed for the flooding, informal settlers in 'danger zones' were evicted by the state and 'returned' to the provinces or relocated to the peri-urban fringe when not left homeless. In organized communities, resistance to 'preemptive evacuation' and 'relocation' was met with threats to 'blast' their homes (Alvarez \& Cardenas, 2019). Two presidential proclamations allocating parcels of land for social housing along the Manggahan Floodway were revoked; and a Supreme Court Mandamus Order pertaining to the rehabilitation of the Manila Bay was marshalled as a basis for 'danger zone' evictions. In the early days of the heady response to Ondoy, the expulsion of informal settlers conformed to the revanchism of dispossession, creating a discursive break between the developmentalist and inclusive rhetoric of the newly reconstituted Philippine DRRM policy (Alvarez \& Cardenas, 2019). However, reforming the reactionary framework of the old DRRM only heightened dispossession, as discourses of Ondoy re-described how evictions were framed, enacted, and implemented (Ibid.).

\subsection{Contexts and shifts: from hostile to benevolent evictions}

By 2013, hostility against informal settlers had softened with the rollout of the One Safe Future 'brand' under the program, 'Securing the Safety of Informal Settler Families in Metro Manila,' which outlined a framework for 'danger zone' evictions premised on 'saving lives' and providing housing solutions for vulnerable slum dwellers. As a strategic approach to facilitating the implementation of the Metro Manila Flood Management Project (MMFMP) and the Informal Settler Families Housing Program, One Safe Future re-scripted the rhetoric and demeanor of 'danger zone' evictions by establishing eviction protocols, creating social 
safeguards, and expanding compliance requirements set by funding agencies. It sought to broaden inclusive mechanisms such as the citizen-led drafting of RRAPs which specify the process of ISF removal and resettlement. These efforts later led to the introduction of The People's Plan, a new housing governance regime that proffered participatory approaches to slum eviction and resettlement. These changes simultaneously echoed and were echoed in the MMFMP and ISF Housing Program which both emphasized citizen participation. Drawn up in response to the Ondoy floods, the MMFMP underscored the importance of 'good practices' which facilitated the removal of tens of thousands of slum dwellers (World Bank Group, 2017, p. 6).

Because the expulsion of informal settlers was crucial to project implementation, slum removals were regarded as key to its success. However, for eviction to be successful, it was politically expedient not only to implement the flood management project and master plan alongside a housing program, or to frame slum clearance as a matter of 'saving lives,' but crucially, to embrace a 'more decentralized participatory' (World Bank Group, 2017, p. 5) approach to expulsion. Cognizant of the failures of top-down and centrally-administered offcity shelter programs in addressing Manila's slum problem, the MMFMP sought to democratize evictions via a series of liberal interventions to resettlement governance. It advocated for adequate consultation with receiving communities, ${ }^{3}$ sufficient preparation for comprehensive People's Plans and RRAPs, expanded assistance and compensation for evictees, and improved grievance redress mechanisms (World Bank Group, 2017). These interventions were earmarked for implementation in the ISF Housing Program, a separate but parallel initiative which aimed to 'ensure the safety of ... ISFs in danger zones' by 'facilitating [their] transfer ... to safe and secure settlements', and 'mainstreaming community-based disaster risk reduction activities in vulnerable communities' (One Safe Future, N.d., p. 1). Conceived in response to the president's Ten-Point Covenant with the Urban Poor, the ISF Housing Program allocated P50 billion over the course of five years (2011-2016) for building homes for 'danger zone' evictees. The National Technical Working Group on Informal Settler Families, an inter-government agency helmed by the Department of the Interior and Local Government (DILG), was created to implement the program and was specifically tasked to 'develop guidelines for the use of the fund' and to 'address the safety' of informal settlers (One Safe Future, N.d., p. 1). But as this 'transfer' and 'resettlement' program was essentially a large-scale eviction scheme tied to the MMFMP, implementing it meant first and foremost clearing informal settlements in 'danger zones.'

Slum removals were enforced under Oplan LIKAS, ${ }^{4}$ a program that consolidated all actions related to providing 'safe and secure settlements' (One Safe Future, N.d., p. 1), alongside the ISF Housing Program whose centerpiece was a participatory planning approach called The People's Plan. Departing from decades of top-down public housing initiatives in the Philippines and following the shift to co-production models in housing interventions across the global South (Boonyabancha, 2009; Fieuw \& Mitlin, 2017), The

\footnotetext{
3 This pertains to communities where resettlement sites are built.

${ }^{4}$ Likas means to evacuate. It is used here as an acronym for Lumikas para Iwas Kalamidad at Sakit, which translates to 'evacuate to avoid calamity and disease.'
} 
People's Plan sought to involve communities in creating, drafting, and generating plans for resettlement housing.

Staging 'danger zone' evictions both as a disaster resilience initiative and an in-city social housing program seemed to attend to the discursive break between the developmental rhetorical commitments of DRRM policy and the deeply hostile practices of disaster risk management in the first three years following Ondoy. This shift in the rhetoric and demeanor of slum evictions echoed the politics of the global urban resilience agenda which underscored principles of participation and inclusiveness (Leitner et al., 2018). It also advanced the Benigno Aquino administration's thrust of 'Daang Matuwid' (The Straight Path) which promised 'transformational leadership' and democratic governance. These frames coalesced into a humanitarian discourse of expulsion that proved vital to enforcing serial evictions in aid of the implementation of the MMFMP. But rather than forwarding a progressive urban politics premised on rights and justice, the democratization of 'danger zone' evictions was enacted as benevolence: as acts of charity and as blessings of goodwill toward the vulnerable yet undesirable poor.

\subsection{Benevolent evictions: evicting to 'save lives'}

Unlike the familiar face of evictions in Manila due to gentrification (Choi, 2016; Ortega, 2016a, 2016b; Arcilla, 2018), 'danger zone' evictions remove informal settlers for a patently less antagonistic reason: they are evicted for their own safety and welfare. As vulnerable subjects, they are removed to protect them from floods and disasters; and as precarious subjects, they are made homeless so they may live in proper homes. While evictions have been portrayed in other contexts as a matter of public welfare and interest (Ocheje, 2007; Bhan, 2016), never in the history of Metro Manila slum evictions has this reason been deployed. Until the One Safe Future agenda which bore Oplan LIKAS and the ISF Housing Program, informal settlers have been traditionally displaced and replaced by development interests in the form of infrastructure and real estate projects (Ortega, 2016a, 2016b), or by 'green' agendas that materialize in waterway rehabilitation programs. Thus, invoking the safety and welfare of the evicted, and cushioning slum removals with social safeguards mark a crucial shift in urban and housing governance. It obscures the injustice and confounds the violence at the heart of what is essentially a political project to rid Manila of its slums.

State personnel candidly recognized the political expediency of 'danger zone' evictions in addressing the slum problem. The changing landscape of Manila's riparian corridors is a veritable illustration. As Figure 1 indicates, the erasure of informal settlements is most visible along the eight priority waterways identified in the MMFMP. Yet despite the scale of demolitions, the belief that 'danger zone' evictions are carried out in the interest of the evicted permeated government. The systematic removal of riparian slums was regarded both as a form of and an opportunity for resettlement. But problematically, such a re-description conveniently forgets that mass eviction underpins mass resettlement. 


\section{Figure 1}

Evicted ISFs in priority waterways under the Metro Manila Flood Management Project, 2012-2017. Data from

National Housing Authority-

National Capital Region.

Cartography by Claudine

Alvarez, produced for author

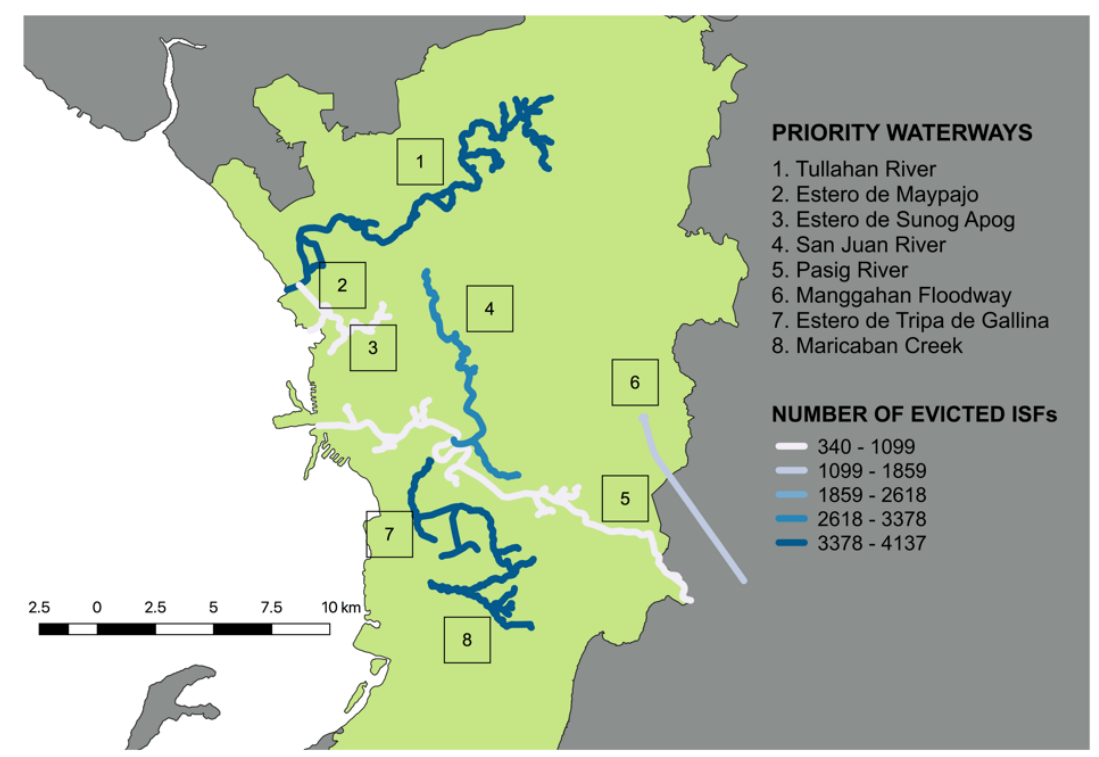

The idea that 'danger zone' evictions are beneficial to the evicted is so insidious yet so compelling because it is easy to understand and difficult to oppose. It proceeds from vulnerability, then startles with glittering generalities of 'saving lives' (Oplan LIKAS), 'safe futures' (One Safe Future), and 'safe and permanent housing solutions' (ISF Housing Program). One is hard-pressed to critique such high-value concepts, especially in the midst of escalating pressures for decisive climate adaptation. However, interrogating these affective ideas reveals that the vulnerable groups they purport to protect are in fact under siege. 'Danger zone' evictions were made so persuasive by the skillful discursive work performed by the state (Alvarez \& Cardenas, 2019) through the demarcation of territories of urban marginality as 'danger zones.' The parallel emergence of the benevolent politics of DRRM instituted punitive welfare policies which were cast in a positive light. Evictions came to be understood not only as necessary acts of disaster governance but more crucially, as welfarist acts of intervention. Framing the demolition of vulnerable slum communities as 'transfer' and 'resettlement' assembled it into an idiom for safe futures and housing solutions.

\section{Organizing housing struggles around benevolent evictions: Reconfiguring community participation and activist contestations}

As new practices of eviction enabled the systematic removal of tens of thousands of families from Manila's 'danger zones,' benevolent evictions simultaneously democratized housing solutions which emphasized co-production. What is remarkable here is not so much these developments, but rather the fact that the state itself had initiated a new governance regime that inscribed citizen participation in planning and administration at the core of what was perceived to be a transformational slum resettlement program. However, as experiences of new governance practices in other contexts show (Blakeley, 2010), this experiment consolidated state power: in Manila, it solidified government's preference for self-help housing and continued the tradition of responsibilizing informal settlers for their shelter needs. 
While most riparian communities that were ordered evicted have fled and transferred mostly to off-city relocation sites, returned to the provinces, or settled elsewhere, others have put up a fight. Those who were most successful in negotiating the terms of their expulsion were organized neighborhood associations supported by civil society organizations (CSOs) and housing federations which perceived 'danger zone' evictions and the disaster resilience agenda as opportunities to demand safe and secure housing futures. The state viewed this resistance with great concern. Settlements along the Manggahan Floodway and the Marikina River were singled out by Pasig officials as problem communities. In interviews, city executives at the helm of evictions spoke of residents and their leaders with contempt. Citing them as nuisance to flood resilience initiatives, local authorities framed community opposition to eviction as an opportunistic act to protect not just their homes but also their alleged interests in the informal housing economy.

It is important to clarify that what makes these communities problematic to the state is not so much their resistance than the fact that they are organized, because organized resistance is much more difficult to quash than diffuse resistance. A keen awareness of rights and improved literacy in bureaucratic processes enable people's organizations to engage more skillfully with the state. As a result, APOAMF has been able to delay evictions, undermine both big-ticket and city-level resilience infrastructure projects, participate in highlevel dialogues, and lead in the formulation of the RRAP. These gains materialized in the construction of the Manggahan Residences: in the completion of the first two buildings for the first phase of the project, as shown in Figure 2, and the construction of the remaining 13 phases, as seen in Figure 3.

Figure 2

The first phase of Manggahan Residences, an incity resettlement project in Pasig City, built through the efforts of APOAMF under The People's Plan. Source: Author, 20 October 2015

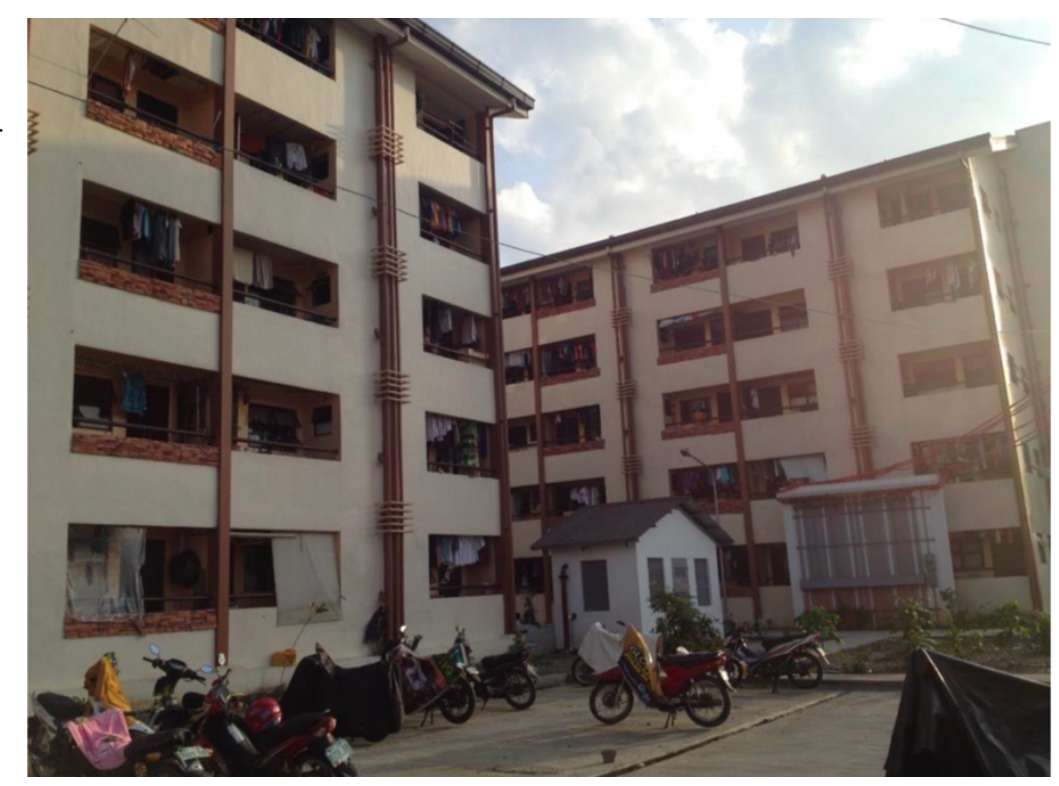




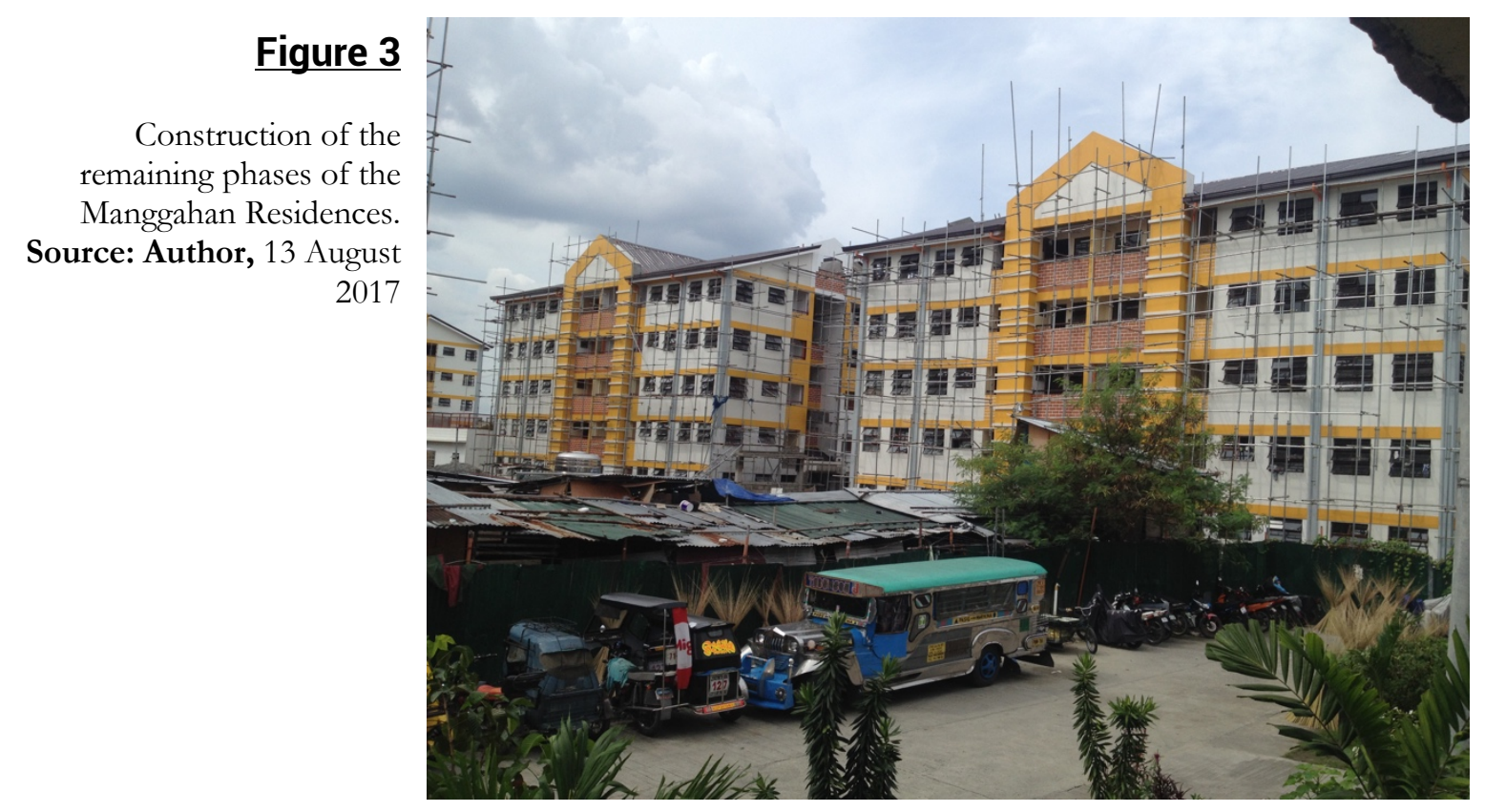

APOAMF's accomplishments did not sit well with the Pasig government. Throughout the life of The People's Plan—from its generation, drafting, and implementation-local authorities blocked progress by rejecting of all sorts of requests: from a simple audience with officials, and assistance in coordinating activities related to the plan, to the more urgent deferral of eviction orders issued by agencies responsible for the MMFMP. The completion of the first phase of the Manggahan Residences in August 2015 further aggravated this hostility. The power and promise of organized resistance, as evinced in the spaces and possibilities it birthed, explain not just this antagonism but the fear that underlies the perception of organized communities as both a threat and a problem.

\subsection{Reconfiguring community participation: new alliances and strategies}

Just as benevolence served as the cornerstone and the politics of 'building back better', participation was likewise made the centerpiece of practices of eviction and relocation. But creating safe futures under Oplan LIKAS and The People's Plan did not merely underscore participation: it enticed with collaboration which undergirded cooperation with the state. One Safe Future's slogan, 'Sama-samang pagkilos para sa mga pamayanang ligtas' (working together for safe communities) encouraged working with the state by engaging in the processes of the state no longer as passive beneficiaries, not even as active participants, but as agentic collaborators in flood-proofing the city.

The conflicting attitudes of the state toward 'danger zone' evictions became the basis for drawing alliances in government. The DILG and the Presidential Commission for the Urban Poor (PCUP) both played a vital role in delaying local evictions and pushing for dislocation and relocation protocols. APOAMF's anti-eviction alliance worked to suspend evictions, oversee compliance with protocols and safeguards, negotiate with local 
government, and bridge concerns to higher authorities. Notably, the DILG created the Resettlement Governance Unit under the National Capital Region office to implement and monitor 'humane' resettlement. These new alliances presented new opportunities and strategies in engaging the state, which were collectively beneficial in light of contradictions in national and local policies and directives.

State alliances were strengthened by partnerships with CSOs and housing federations. APOAMF worked closely with Community Organizers Multiversity (COM) which helped leaders secure a seat in important policy forums and negotiations, notably the 2014 drafting of the Manggahan Floodway RRAP and the 2015 National Housing Summit. Nurturing these strategic relations was critical to the struggle, more so because the oppositional stance of local government and shelter agencies, which both had a mandate on land and housing, prevented the formation of an alliance. This placed residents at a severe disadvantage, as land was at the center of their struggle and there were limits to what DILG and PCUP could accomplish.

This limitation was a fragile spot, because more than nurturing these relations, it implied the unviability of transgressive resistance against the state, hence the recourse to law and policy. At times, it was strategic to declare, despite APOAMF's strong opposition to eviction and resettlement, that it was not opposed to the resettlement itself, but to the sweeping demolitions amidst persistent problems and delays in the construction of both the Manggahan Residences and Pasig's off-city relocation projects. Taking this position likewise carried the added benefit of demonstrating their commitment to the program's notion of participation as cooperation.

\subsubsection{Fragmented and burdensome: what participatory planning looked like}

The emphasis of benevolent evictions on participation meant that adequate consultation with evicted households and receiving communities were carried out more diligently than usual, chiefly through the efforts of PCUP and DILG which acted as stewards of the state's commitment to democratized housing solutions. The RRAP, which specifies the terms of eviction and resettlement, serves as a good illustration, as APOAMF played an active role in its drafting and were involved in subsequent meetings convened by PCUP to resolve disagreements during negotiations.

Beyond this alliance, implementing meaningful participation was fraught with difficulty as the local government and national agencies (particularly the NHA, Department of Public Works and Highways, and Metropolitan Manila Development Authority) skirted participation guidelines and railroaded demolitions by concealing information, misrepresenting claims, and threatening forced removal. For example, Pasig officials excluded APOAMF from the local government's initiative of finding 'near-site' relocation alternatives, whereas the NHA withheld information regarding the coverage of previous presidential proclamations declaring the embankments of Manggahan Floodway areas for socialized housing. Attempts by these state actors to comply with commitments to citizen participation took the form of what Arnstein describes as an 'empty ritual of participation' 
(1969, p. 216). Instead of discussions preceding from residents' demands and their vision informing plans, the agenda of flood control proponents in government served as the reference points: consultations were used as avenues to persuade and dissuade according to their own agenda.

Moreover, while the program encouraged democratization in processes of eviction and co-production in housing solutions, it did so by decentralizing and delegating all tasks to community associations. This outsourcing of labor to beneficiaries spanned all aspects of building and community design, land acquisition, construction monitoring, property management, and community governance (Patiño, 2016, p. 29). The antagonism of local government whose support was central to the success of the program further aggravated this burden. But as the experience of APOAMF attests, the burdens offloaded by the state were cushioned by residents' own dedication to the hope and promise of home and tenure. The allure of homeownership (Ortega, 2016b), and the necessity of citizenship, aligned the desires of informal settlers with the expressed vision of the state, which helped legitimize the centering of flood control, disaster risk management, and climate resilience around demolition, eviction, and relocation.

These losses and gains highlight both the importance and benefits of working with CSOs and establishing linkages with homeless federations (Mitlin \& Satterthwaite, 2004; D'Cruz \& Satterthwaite, 2005). Influential actors such as the Urban Poor Alliance (UP-ALL), of which APOAMF is a member, have access to the state and its development partners and are usually involved in some capacity in negotiating the terms of certain housing programs since they are often approached by government for its 'inclusive' initiatives. The most strategic and well-connected among these federations are able to influence national policy, just as UP-ALL had successfully included on-site and in-city resettlement and participatory housing solutions in the Aquino administration's priority agenda. Urban poor federations play the crucial role of intermediary between informal settlers and government while advocating the interests of the former. But more important, they place communities and their associations at the center and at the forefront of the housing struggle. The technical and organizational skills development trainings provided by CSOs like COM to community associations such as APOAMF have enabled young community associations not only to complete projects or to scale up initiatives (see Boonyabancha, 2009), but also to engage more skillfully with the state and to contest and counteract more effectively. Most crucially, technical support plants seeds of autonomy.

\subsubsection{Participation under The People's Plan: Is it really participation?}

For all the state's demands to work in unison, it was in fact government agencies and offices that refused cooperation and violated principles of participation. Notwithstanding the accomplishments of the ISF Housing Program, as carried out, participatory planning was oppressive and burdensome. As an APOAMF leader lamented: 'They burdened us. They really burdened us' (Personal interview, 30 October 2015). Though pertaining specifically to the local government, these sentiments generally describe their encounters with the state and 
their overall experience with The People's Plan. Co-production was supposed to alleviate 'housing as a field of immanent political struggle' (Gray, 2018b, p. xviii), but it ended up aggravating hardships.

The exclusions that result from implementing participatory housing solutions begs the question: is it really participation? In attempting an answer, it is useful to note that 'participation emerges ... as the "banner" of everybody' (Fiori \& Ramirez, 1992, p. 28). The 'rhetoric of citizen control' (Arnstein, 1969, p. 223) is invoked by a range of actors spanning the spectrum of ideology (Fiori \& Ramirez, 1992, p. 28), hence the plurality of styles and meanings (Arnstein, 1969). But at the same time, the misuse of the term to describe marginal involvement warrants attention; and here, Arnstein's (1969) 'ladder of citizenship participation' offers an instructive guide. The eight rungs consist of manipulation, therapy, informing, consultation, placation, partnership, delegated power, and citizen control (Arnstein, 1969). While individual rungs overlap in practice, this typology nonetheless depicts the typical forms of participation. It shows how citizen involvement is mobilized for tokenistic purposes (to engineer support for powerholders' agenda, rectify a perceived pathology, disseminate information, and restrict inputs in consultation) but also able to acquire some degree of influence (through the grant of restricted access to the decisionmaking process, partnership in decision making and implementation, and citizen control) (Arnstein, 1969).

Under The People's Plan, APOAMF hovered between informing and placation. In meetings and consultations with the local government in contexts where the latter were forced to fulfil inescapable obligations stipulated in the program guidelines, authorities merely went through the motions of letting the community 'participat[e] in participation' (Arnstein, 1969, p. 219). Questions were discouraged, inputs were restricted, and information was simply disseminated. Although the program itself charged neighborhood associations with the responsibility_often painted by implementers, allies, and residents alike as opportunity - to generate and implement their housing plan, it made the execution of both extremely difficult. In the first instance, the process was tedious: the foremost requirement of getting accredited either as a housing cooperative or neighborhood association involves lengthy procedures and an equally lengthy validation period (Patiño, 2016, p. 32-34, 39). Succeeding stages of plan development, financing approval, land acquisition, fund disbursement, and project construction were further beset by delays, restrictions, and opposition notably at the local level (for similar experience of other communities in Metro Manila, see Patiño, 2016). In spite of allies' efforts to forge a semblance of partnership with APOAMF, overall, program delivery sabotaged success because opponents hijacked an already fragmented process splintered by actors' conflicting priorities and intense politicking (Patiño, 2016, pp. 37-38). But the fact that actively blocking participation was at all possible points to the concentration of power in the hands of government. It further suggests that the program treated participation as a good dispensed by the benevolent state.

Democratizing housing solutions did not necessarily result in the democratization of participation, as it neither reconfigured power relations nor did it aim to do so. The People's Plan was plagued by conflicting 'systems of thought and practice' which specify a 
participatory framework yet conform to top-down methods of decision making (Patiño, 2016, p. 33). This paradox cannot be understood outside the contradictions of the ISF Housing Program whose main intent was to clear slums and whose primary accountability was to the flood control program. The state's commitment to flood resilience far exceeded its covenant with the urban poor, but it found ways to bridge both priorities by discursively producing 'danger zone' evictions as an opportunity to secure homes and safe futures, and by materializing this in the democratization of eviction and relocation. As a mechanism to execute this compromise, The People's Plan merely envisaged expanding inclusion, and in doing so, entrenched the equivalency between self-empowerment and participation. Relying on inclusion and self-help, it sought instead to redistribute a sense of ownership in both process and outcome, neither by handing over control nor redistributing power, but by delegating the most vital aspects of planning and implementation to resident-beneficiaries and painting it as the essence of participation. While ownership, cooperation, and collaboration are not equivalent to participation, this framing organized state-slum relations under The People's Plan. It cloaked the state's preference for self-help housing, thereby making it alluring to informal settlers who have always been the object of (exclusion in) planning and as such were enthusiastic about a landmark housing program.

However, as the experience of participatory governance programs in other contexts illuminates (Cooke \& Kothari, 2001; Blakeley, 2010), control of the agenda, of the process, and of participation rested entirely with the state, with the local government exerting or usurping much of it. For instance, despite the stipulated prioritization of on-site and in-city relocation in the Operational Guidelines for The People's Plan, the Manggahan Floodway RRAP nevertheless specified a preference for the local government's in-city and near-city relocation housing projects which APOAMF had previously rejected.

Whereas communities were granted some input into housing solutions, this did not extend to flood control which is at the core of massive evictions under the ISF Housing Program. Communities did not have any input on where evictions would happen: the state delineated Metro Manila's 'danger zones.' Neither did they have a say in whether it happens: flood resilience via slum clearance was the backbone of the housing program. Only the terms of eviction were open to participation, yet even then, the program allowed state interference. Decoupling these programs and limiting participation to a sphere which government thought residents had the most stake in ensured that the priorities of flood control remained intact and inscrutable. Protecting the integrity of the flood resilience agenda at the expense of a watered-down participatory housing program offers insight into why the fight for the 'right to stay put' (Hartman, 1984; see also Weinstein, 2014) did not prosper except in certain instances where the slum was un-slummed via the aesthetic reconfiguration of space (i.e., pushing back settlements beyond the three-meter easement, beautifying waterways, and facelifting homes).

All this orients our attention to the need to interrogate the claim that The People's Plan was participatory. Although it incorporated a number of elements of participation, participation itself was in fact directed, administered, and regulated by the benevolent state. Paradoxically, expanding inclusion did not necessarily limit government power (Blakeley, 
2010). On the contrary, program implementation and success relied, to a large extent, on the good graces of government, particularly on community associations cultivating good relations with key state actors. The little respite that the state allowed or that residents managed to crack open was curtailed at the slightest threat of destabilizing power relations. If, as Patiño suggests (2016, p. 41), harmonious coexistence with powerholders determines the success of The People's Plan, and if redistributing power to citizens is perceived as a disruption, then as it stands, there is little merit to the participation the program boasts.

Such enclosures instead reveal the governmentality at the heart of the state's notion of participation (Taylor, 2007; Blakeley, 2010). The supplication that citizen inclusion entailed further attests to this. The burdensome process and the fierce opposition residents encountered compelled seeking intercession especially in the face of imminent eviction. In letters to government authorities, residents repeatedly invoked their rights and entitlements under various laws, and reiterated the commitments of local government and concerned agencies under the policy guidelines. But while they urged the state to put people at the center of community development and asserted that such initiatives should in fact be led by them, the overall tone across correspondences bore pleas for cooperation, compassion, and intervention.

If participation were exercised through The People's Plan, it was because it was won through political struggle. It was due neither to the state nor to the architects of the program, but rather to the members of APOAMF who persevered to make participation participatory. But just as the democratization of housing solutions did not necessarily result in the democratization of community inclusion, organized community resistance within the arena of the state likewise did not necessarily increase informal settlers' bargaining power.

\subsection{Reconfiguring activist contestations}

In encouraging collaboration and cooperation as modes of participation, benevolent evictions via The People's Plan simultaneously discouraged dissent and contestation. The rhetoric of sama-sama (collective action) was vital to both the housing program and the flood resilience project precisely because of its potential to stave off oppositional practices. Although housing cooperatives like the Alyansa ng Mamamayan sa Valenzuela and Dario River Alliance were able to successfully stage a picket outside the central office of one of the shelter agencies over delays in the approval of proposals (Patiño, 2016, p. 38), in general, working with the state excluded the mobilization of dissident approaches from viable forms of redress. Because participation was wielded as weapon and gift, community organizations remained at the mercy of the state. Informal settlers remained beneficiaries under the paternalistic participatory politics of The People's Plan; however, APOAMF's exercise of agency challenged this subjectivity. While residents echoed the beneficiary trope partly as a tactic to extract concessions, in their engagement with the state and even in their pleas for compassion and intercession, they simultaneously asserted their position as clients of government to whom obligations were due. 
The forging of this new identity drew from subjectivities of citizenship implied in the program's model of participation. The creation and implementation of The People's Plan was understood also as an opportunity for Manila's urban poor to overturn the stigma of the slum dweller as the uncouth and undisciplined other. The use of 'participatory civic culture' to describe the program and distinguish it from conventional 'contentious actions' and 'extralegal means' of protest against evictions (Patiño, 2016, p. 41), illustrates how program proponents and advocates cast it as a transformational method of collective housing action while discouraging resistance. Informal settlers' burden to prove themselves capable of cooperation, collaboration, and civility — thus, worthy of citizenship-deterred insurgent practices of political organizing in favor of 'formal channels for citizen participation and claims' (Miraftab, 2009, p. 34). As a tactic and recourse, radical engagement was deemed politically unviable. Militant action even in the face of government suppression and oppression would have sabotaged APOAMF's already precarious resettlement project because its life relied on the vast powers wielded over the program by its political opponents. Under these circumstances, it was more strategic to mobilize their alliances and politically expedient to secure a 'concrete solution' to the eviction crisis rather than forwarding 'oppositional dialectics' through radical action (Di Feliciantonio, 2017, p. 52).

The exclusion of confrontational activist contestations from communities' arsenal of viable resistance opens up questions about the limits and politics of this model of participation. At the same time, it invites reconsideration and reconfiguration of the possibilities and practices of dissent among housing associations whose cooperative relations with the state are crucial for winning both incremental gains and substantive victories. Interestingly, in spite and because of its problems, the most hopeful promise that participatory planning holds seems to be the legislative proposal to institutionalize The People's Plan via the establishment of a local on-site, in-city, or near-city resettlement program that would continue the unfinished mandate of the ISF Housing Program. The contradictions that surface present a 'sphere of possibility' (Crossley, 2017, p. 1; see also Massey, 2005): a corrective potential to rewrite the politics of cooperative housing models in ways that are attentive to the redistribution of power, the reconfiguration of political participation, and the transformation of citizenship and slum-state relations. It urges the repoliticization of housing strategies that consolidate the defensive and offensive (Joubert \& Hodkinson, 2018), and that revoke persuasions of insurgent contestations as a risk and liability (Mitlin, 2018). Discouraging radical approaches in the midst of conciliatory evictions at a time of intensifying assault against the right to shelter ignores the political immediacy of the fight for life and home.

Correspondingly, the success and promise of housing cooperatives like APOAMF amidst persistent state repression also offers lessons on the organizing practices of top-down urban poor organizations like Kadamay (Kalipunan ng Damayang Mahibirap), whose momentous occupation of idle social housing projects in March 2017 prompts a shift in understandings of Manila and its problems in terms of urban dispossession and banishment (Alvarez, 2018). APOAMF's experience illuminates the emancipatory potential of skills and knowledge sharing (see Boonyabancha, 2009), wherein the objective of community 
organizing surpasses political mobilization in favor of the creation of autonomous neighborhood associations.

What is needed, after all, are 'insurgent, constitutive movements that seek radical social change via collective "social force" rather than promoting vain hopes for recognition' (Gray, 2018a, p. 214). This radicalism does not end at methods or aims, but rather extends to political participation and relations. The benevolent turn of evictions-its reframing as resettlement and resilience-building, and its re-description as opportunity-underscores the need for a plurality of tactics, a diversity of collective resistance (Cooper \& Paton, 2018), and the mobilization of defensive and offensive strategies (Joubert \& Hodkinson, 2018). The institutionalization of The People's Plan via the 'Local Government Unit Led On-site, Incity or Near-City Resettlement Act', which is similarly predicated on clearing Manila's slums, underlines the urgency of re-politicizing participation, for relocation and resettlement cannot be divorced from wider processes of urban dispossession. That 'near-city' relocation, a contentious category which the state has habitually interpreted as adjacent suburbs, is listed as a resettlement option does not bode well for the promise of 'safe futures', for it has time and again resulted in the forced exodus of informal settlers. Preventing this danger requires not so much the intercession of allies and vanguards in government and civil society than the exercise of radical citizenship (Holston, 1995), the reorientation towards insurgent planning' (Miraftab, 2009), and the defense of community governance. The legitimation of a massive slum eviction program through the deployment of benevolence calls upon modes of participation that go beyond merely being included (Kaika, 2017, p. 96), and demands activisms that are 'counter-hegemonic, transgressive, and imaginative' (Miraftab, 2009, p. 32).

\section{Conclusion}

This paper forwarded the concept of benevolent evictions to describe a new mode of dispossession, whereby expulsions from the urban core to the periphery are facilitated through the deployment of benevolence as a technology of eviction. Drawing on the experience of APOAMF, it examined how benevolent evictions in Metro Manila, as materialized in The People's Plan, reconfigured community participation and activist contestations. Particularly, it inquired into the formation of alliances and the changes in strategies, critically assessed the politics of participation by probing practices of inclusion in housing affairs and exclusion in flood control matters, and considered the implications of participation on transgressive practices of organizing around housing struggles.

The rhetoric and politics of benevolent evictions reveal the revanchism of benevolence as an approach, a strategy, and a politics of evictions. This turn to benevolence echoes blunt calls for new urban paradigms which nevertheless remain faithful to maintaining conventional configurations of power and social relations (Kaika, 2017, p. 89). Fortunately, the contradictions that emerge presents political possibilities for undermining state hegemony (Miraftab, 2009; Mitlin, 2018) and claiming political power (Taylor, 2007; O'Hare, 2018). For community associations like APOAMF, this points to the need to transform relations of participation while subsumed under formal governance regimes (O’Hare, 2018, 
p. 210), by embracing a diversity of defensive and offensive strategies (Joubert \& Hodkinson, 2018). These do not shun insurgent contestation but rather view it as a parallel and contemporaneous approach (Mitlin, 2018), and understand its place in the housing struggle. After all, some of the most momentous victories in the long history of the fight for the right to shelter were won through transgressive action (Cowley, 1979; Gray, 2018c).

Although this may present some difficulties for new community associations mobilized by less confrontational CSOs and federations, the transformation of subjective relations via the reconstitution of resistance strategies is an urgent undertaking as housing is attacked on all fronts and evictions are increasingly made benevolent. Besides subverting the revanchist logics of benevolence, citizen control of 'transformational' participatory housing programs reorients attention to the underlying aim of birthing new slum-state and citizen-state relations (Miraftab, 2009). This re-politicization of participation is crucial for reimagining and enacting the politics and promise of citizen involvement in planning and governance (Taylor, 2007; Boonyabancha, 2009; Doering, 2014; Fieuw \& Mitlin, 2017; O’Hare, 2018). Such a critical task demands the same urgency as the state's pursuit of flood 'resilience': it is most needed at a time of persuasive justifications for slum clearance under programs like The People's Plan, whose benevolence and allure as a governance intervention (Patiño, 2016) requires critical scrutiny.

The concept of benevolent eviction serves as a useful framework for understanding the new drivers and logics of dispossession in climate-vulnerable Southern cities subjected to reconstruction and reconfiguration both in the aftermath of disasters and in response to escalating risks. Benevolent eviction is an instantiation of 'resiliency revanchism', or 'the discursive enrolment of resiliency toward revenge' against the vulnerable yet undesirable other (Alvarez \& Cardenas, 2019, p. 246). Beyond displacement in post-disaster contexts (Neto \& Heller, 2016; Yee, 2018) and landscapes of risk (Collins, 2009; Zeiderman, 2012; Saguin, 2017; Millington, 2018), understanding how benevolence is deployed in both rhetoric and practice towards the expulsion of marginalized populations resonates in contexts where logics of welfare, care (Lancione, 2014), public safety, and public interest (Ocheje, 2007; Bhan, 2016) are mobilized in policies on homelessness, eviction, and relocation. Recognizing nascent processes that underpin contemporary expulsions alerts us to new principles and practices of eviction. In the face of an escalating housing crisis and a creative turn in arguments for banishment, cultivating such an attention is vital as these developments impinge on tactics and strategies of organizing.

\section{Acknowledgements}

I wish to thank the three anonymous reviewers for their valuable feedback, and the editors of this issue, especially Michele Lancione, for their solidarity in the midst of illness during revisions. Gratitude is also due to Maria Amparo Warren and Kreeger Bonagua for their inputs, Claudine Alvarez for sharing her resources and producing the map, and Kristian Saguin for helping edit the manuscript. I am grateful to my research participants, especially the members of APOAMF, whose generosity helped make this paper possible. 


\section{References}

Aalbers, M. B. (2017) The variegated financialization of housing, International Journal of Urban and Regional Research, 41(4), pp. 542-554.

Alvarez, M. K. (2018) \#OccupyPabahay and the politics of placelessness: Dispatches from Manila, Philippines, The Funambulist, 20, November-December, pp. 4-5.

Alvarez, M. K. \& Cardenas, K. (2019) Evicting slums, 'building back better': Resiliency revanchism and disaster risk management in Manila, International Journal of Urban and Regional Research, 43(2), pp. 227-249.

Arcilla, C. A. C. (2018) Producing empty socialized housing: Privatizing gains, socializing costs, and dispossessing the Filipino poor, Social Transformations, 6(1), pp. 77-105.

Arnstein, S. R. (1969). A ladder of citizen participation, Journal of the American Planning Association, 35(4), pp. 216-224.

Bhan, G. (2016). In the Public's Interest: Evictions, Citizenship, and Inequality in Contemporary Delhi. Geographies of Justice and Social Transformation (Athens, Georgia: University of Georgia Press).

Blakeley, G. (2010). Governing ourselves: Citizen participation and governance in Barcelona and Manchester, International Journal of Urban and Regional Research, 34(1), pp. 130-145.

Boonyabancha, S. (2009) Land for housing the poor - by the poor: Experiences from the Baan Mankong nationwide slum upgrading programme in Thailand, Environment and Urbanization, 21(2), pp. 309-329.

Byrne, M. (2018) Tenant self-organization after the Irish Crisis: The Dublin Tenants Association, in: N. Gray (Ed) Rent and Its Discontents: A Century of Housing Struggle, pp. 8599 (London: Rowman \& Littlefield International).

Choi, N. (2016) Metro Manila through the gentrification lens: Disparities in urban planning and displacement risks, Urban Studies, 53(3), pp. 577-592.

Colau, A. \& Alemany, A. (2013). Mortgaged Lives: From the Housing Bubble to the Right to Housing. (M. Teran \& J. Fuquay, Trans.) (Los Angeles: Journal of Aesthetics \& Protest Press). (Original work published 2012).

Collins, T. (2009). The production of unequal risk in hazardscapes: An explanatory frame applied to disaster at the US-Mexico border, Geoforum, 40(4), pp. 589-601.

Cooke, B. \& Kothari, U. (Eds) (2001). Participation: The New Tyranny? (New York: Zed Books).

Cooper, V. \& Paton, K. (2018) Everyday evictions in the twenty-first century, in: N. Gray (Ed) Rent and Its Discontents: A Century of Housing Struggle, pp. $71-84$ (London: Rowman \& Littlefield International).

Crossley, S. (2017) In Their Place: The Imagined Geographies of Poverty (London: Pluto Press).

Cowley, J. (1979) Housing, for People or for Profit? (London: Stage 1).

D'Cruz, C. \& Satterthwaite, D. (2005) Building Homes, Changing Official Approaches: The Work of Urban Poor Organizations and Their Federations and Their Contributions to Meeting the Millennium Development Goals in Urban Areas IIED Poverty Reduction in Urban Areas Series Working Paper 16, London, United Kingdom: International Institute for Environment and Development.

Di Feliciantonio, C. (2017) Social movements and alternative housing models: Practicing the 'politics of possibilities' in Spain, Housing, Theory and Society, 34(1), pp. 38-56.

Doering, H. (2014). Competing visions of community: Empowerment and abandonment in the governance of coalfield regeneration, International Journal of Urban and Regional Research, 38(3), pp. 1003-1018.

Dorling, D. (2014) All That Is Solid: How the Great Housing Disaster Defines Our Times, and What We Can Do About It (London: Penguin Books).

Fields, D. (2018) Constructing a new asset class: Property-led financial accumulation after the crisis, Economic Geography, 94(2), pp. 118-140.

Fieuw, W. \& Mitlin, D. (2017) What the experiences of South Africa's mass housing programme teach us about the contribution of civil society to policy and programme reform,

Environment and Urbanization, 30(1), pp. 215-232. 
Fiori, J. \& Ramirez, R. (1992). Notes on the self-help housing critique: Towards a conceptual framework for the analysis of self-help housing policies in developing countries, in: M. Kosta (Ed) Beyond Self-Help Housing, pp. 23-31 (London/New York: Continuum International Publishing Group Ltd.)

Gray, N. (2018a) Afterword: The futures of housing activism, in: N. Gray (Ed) Rent and Its Discontents: A Century of Housing Struggle, pp. 201-217 (London: Rowman \& Littlefield International).

Gray, N. (2018b) Introduction: Rent unrest: From the 1915 rent strikes to contemporary housing struggles, in: N. Gray (Ed) Rent and Its Discontents: A Century of Housing Struggle, pp. xvii-xxxix (London: Rowman \& Littlefield International).

Gray, N. (Ed) (2018c) Rent and Its Discontents: A Century of Housing Struggle (London: Rowman \& Littlefield International).

Hartman, C. (1984) The right to stay put, in: C. Geisler \& F. Popper (Eds) Land Reform, American Style, pp. 302-309 (Totowa, NJ: Rowman \& Allanheld).

Holston, J. (1995) Spaces of insurgent citizenship, Planning Theory, 13, pp. 35-51.

ICF International (2014). Developing a national informal settlements upgrading strategy for the Philippines: Final report, July 2014. Available at: http://www.hudcc.gov.ph/sites/default/files/styles/large/public/document/NI SUS\%20Final\%20Report_July2014.pdf (Accessed 1 February 2019).

Joubert, T. \& Hodkinson, S. (2018) Beyond the rent strike, towards the commons: Why the housing question requires activism that generates its own alternatives, in: N. Gray (Ed) Rent and Its Discontents, pp. 185-200 (London: Rowman \& Littlefield International).

Kaika, M. (2017) 'Don't call me resilient again!': The New Urban Agenda as immunology ... or ... what happens when communities refuse to be vaccinated with 'smart cities' and indicators, Environment and Urbanization, 29(1), pp. 89-102.

Lancione, M. (2014) Assemblages of care and the analysis of public policies on homelessness in Turin, Italy, City, 18(1), pp. 25-40.

Leitner, H., Sheppard, E., Webber, S. \& Colven, E. (2018) Globalizing urban resilience, Urban Geography, 39(8), pp. 1276-1284.

Maringanti, A. (2013) Ordinary entanglements in the world city, Environment and Planning A: Economy and Space, 45(10), pp. 2314-2317.

Massey, D. (2005) For Space (London: Sage).

Millington, N. (2018). Linear parks and the political ecologies of permeability: Environmental displacement in São Paulo, Brazil, International Journal of Urban and Regional Research, 42(5), pp. 864-881.

Miraftab, F. (2009) Insurgent planning: Situating radical planning in the global south, Planning Theory, 8(1), pp. 32-50.

Mitlin, D. (2018) Beyond contention: Urban social movements and their multiple approaches to secure transformation, Environment and Urbanization, 30(2): 557-574.

Mitlin, D. \& Satterthwaite, D. (2004) The role of local and extra-local organizations, in: D. Mitlin \& D. Satterthwaite (Eds) Empowering Squatter Citizen: Local Government, Civil Society and Urban Poverty Reduction, pp. 278-306 (London: Earthscan).

Neto, D. J. D. A. \& Heller, L. (2016) Which is riskier: life on the floodplain or in housing imposed from above? The case of flood-prone areas in Rio Branco, Acre, Brazil, Environment and Urbanization, 28(1), pp. 169-182.

O'Hare, P. (2018). Resisting the 'long-arm' of the state? Spheres of capture and opportunities for autonomy in community governance, International Journal of Urban and Regional Research, 42(2), pp. 210-225.

Ocheje, P. D. (2007). 'In the public interest': Forced evictions, land rights and human development in Africa, Journal of African Law, 51(2), pp. 173-214.

One Safe Future (N.d.) 1SF One Safe Future: A Communication Plan for the Department of the Interior and Local Government (DILG) Program on Securing the Safety of Informal Settler Families (ISF) in Metro Manila Unpublished report, Quezon City, Philippines: One Safe Future. 
Ortega, A. A. C. (2016a) Manila's metropolitan landscape of gentrification: Global urban development, accumulation by dispossession and neoliberal warfare against informality, Geoforum, 70, pp. 35-50.

Ortega, A. A. C. (2016b) Neoliberalizing Spaces in the Philippines: Suburbanization, Transnational Migration, and Dispossession (Lanham, Maryland: Lexington Books).

Patiño, P. I. (2016) Building Resilient and Safe Communities against Poverty and Disaster Asian Cities Climate Resilience Working Paper Series 29, London: International Institute for Environment and Development.

Philippine Statistics Authority (2015) Census of Population, Quezon City: Philippine Statistics Authority.

Saguin, K. (2017) Producing an urban hazardscape beyond the city: Environment and Planning A: Economy and Space, 49(9), pp. 1968-1985.

Taylor, M. (2007) Community participation in the real world: Opportunities and pitfalls in new governance spaces, Urban Studies, 44(2), pp. 297-317.

Weinstein, L. (2014) The Durable Slum: Dharavi and the Right to Stay Put in Globalizing Mumbai (Minneapolis, MN: University of Minnesota Press).

World Bank Group (2017) Philippines - Metro Manila Flood Management Project (English) Project Appraisal Document, Washington, D.C.: World Bank Group. Available at: http://documents.worldbank.org/curated/en/192891506823261036/pdf/PHILIPPINE S-PAD-09082017.pdf (Accessed 10 January 2019)

Yee, D. K. P. (2018) Constructing reconstruction, territorializing risk: Imposing 'no-build zones' in post-disaster reconstruction in Tacloban City, Philippines, Critical Asian Studies, 50(1), pp. 103-121.

Zeiderman, A. (2012) On shaky ground: The making of risk in Bogotá, Environment and Planning A: Economy and Space, 44, pp. 1570-1588. 